\title{
Pengaruh Model Pembelajaran Terhadap Hasil Belajar Siswa pada Materi Pencemaran Lingkungan di SMA Negeri 1 Bendahara Aceh Tamiang
}

\author{
Fauzi $^{1 *}$, Binari Manurung ${ }^{2}$, Syahmi Edi $^{2}$ \\ ${ }^{1}$ Alumni Program Studi Pendidikan Biologi Pascasarjana Universitas Negeri Medan \\ ${ }^{2}$ Prodi Pendidikan Biologi PPs Universitas Negeri Medan, Sumatra utara, Indonesia \\ *Email: fauzi_mpd@yahoo.com
}

\begin{abstract}
This research aim to investigate the effect of learning model to students learning outcomes in environmental pollution subject matter. This research method was quasi experimental design with pretest and posttest control group design. Research population in this research was the whole Grade $\mathrm{X}$ students in SMA Negeri 1 Bendahara academic year 2015/2016 as much as 120 students. Samples of this research were 3 regular classes of Grade $X$ with total 90 students. Samples of this research were choosen based on special criteria (purpossive sampling). Data were collected using test instrument. Data analysis technique was using analysis of covarians. The result of study showed that there was a significant effect of learning models (project and problem based learning) to students outcome. (Fcount $=16,46 ; \mathrm{P}=0,00)$. Based on this study result, it can be concluded that students outcome which taught using project based learning model was higher than problem based learning and convensional learning models.
\end{abstract}

Keywords: Project based Learning, Learning outcome, environmental pollution.

\section{PENDAHULUAN}

Pendidikan merupakan faktor yang sangat penting bagi siswa/i dalam mejalani kehidupan. Melalui pendidikan siswa/i dapat mengembangkan kemampuan di dalam dirinya sesuai dengan ilmu pengetahuan yang telah diperoleh sehingga mampu menghadapi perkembangan dan perubahan yang terjadi di linkungan sekitarnya. Oleh karena itu, diperlukan perhatian lebih berkenaan dengan masalah pendidikan sehingga mampu mengembangkan potensi peserta didik. Proses pembelajaran pada pendidikan harus interatif, inpiratif, menyenangkan dan dapat memotivasi peserta didik untuk aktif, kreatif dan kemadirian sesuai bakat, minat dan perkembangan fisik serta psikologi peserta didik (Kemendiknas, 2007).

Salah satu mata pelajaran yang sesuai dengan pendidikan lingkungan hidup adalah biologi. Pendidikan lingkungan hidup perlu diberikan kepada peserta didik agar terbentuk kesadaran dan sikap peduli lingkungan sejak dini. Tujuannya untuk mendorong terciptanya pengetahuan dan kesadaran peserta didik di sekolah dalam upaya pelestarian lingkungan hidup (Wahyuningtyas $d k k, 2013$ ).
Berdasarkan observasi yang dilakukan melalui wawancara denagan guru biologi di SMA Negeri 1 Bendahara ditemukan bahwa proses pembelajaran masih menerapkan metode ceramah, dan tanya jawab. Hal ini dibuktikan bahwa metode ceramah masih dinilai sebagai metode yang paling efektif untuk mentransfer materi pembelajaran kepada siswa. kurangnya memanfaatkan fasilitas yang tersedia seperti infokus dalam menyampaikan materi pelajaran. Hal ini membuat pembelajaran kurang menarik, dan tidak inovatif. Kurangnya perhatian siswa dalam proses pembelajaran, ini di buktikan dengan sesekali mereka berbicara dengan teman yang lain. Siswa jarang sekali bertanya, dan tidak mau menjawab pertanyaan yang diajukan oleh guru, siswa aktif akan semakin aktif, dan sebaliknya.

Hasil belajar biologi masih di bawah ketuntasn yaitu 73 . Nilai rata-rata ujian semester tahun 2012/2013 semester gasal yaitu 67 , semester genap yaitu 68. Tahun 2013/2014 semester gasal yaitu 68, semester genap yaitu 68. Untuk mengatasi permasalahan tersebut, diperlukan suatu model pembelajaran yang dapat memaksimalkan keterlibatan siswa dalam kegiatan pembelajaran. Model 
pembelajaran yang dapat diterapkan dalam proses pembelajaran yaitu model pembelajaran berbasis proyek dan berbasis masalah.

Pembelajaran berbasis proyek merupakan model belajar mengajar yang melibatkan siswa untuk melakukan sebuah proyek yang bermanfaat untuk menyelesaikan permasalahan masyarakat atau lingkungan. Pembelajaran berbasis proyek merupakan salah satu alternatif pembelajaran yang bisa digunakan tidak hanya untuk menilai aspek kognitif, tetapi juga unjuk kerja siswa (Hayati $d k k, 2013)$.

Selain itu, para siswa melakukan sendiri penyelidikannya, bersama kelompoknya sendiri, sehingga memungkinkan para siswa dalam tim tersebut mengembangkan keterampilan melakukan riset yang akan bermanfaat bagi pengembangan kemampuan akademis mereka. Para siswa tersebut tersebut merancang, melakukan pemecahan masalah, melaksanakan pengambilan keputusan dan kegiatan penyelidikan dengan cara membuat proyek. Pembelajaran proyek yang cermat membantu memastikan bahwa proyek akan menatang, manarik minat dan mambantu siswa mencapai tujuan proyek sekaligus mendorong mereka untuk menikmati tugas mereka tersebut (Ballanca, 2012).

Pembelajaran Berbasis Masalah merupakan pembelajaran yang penyampaiannya dilakukan dengan cara menyajikan suatu permasalahan, mengajukan pertanyaan, memfasilaitasi penyelidikan, dan membuka dialog. Pembelajaran yang dikaji hendak merupakan maslah kontekstual yang ditemukan oleh peserta didik dalam kehidupan sehari-hari (Sani, 2014). Untuk memperoleh informasi dan mengembangkan konsep-konsep sains, siswa belajar tentang bagaimana membangun kerangka masalah, mencermati, mengumpulkan data, dan mengorganisasikan masalah, menyusun fakta, menganalisis data, dan menyusun argumentasi terkait pemecahan masalah, baik secara individual maupun dalam kelompok.
Kelebihan PjBL dan PBL adalah kedua model ini menggunakan pendekatan saintifik yang mempunyai langkah-langkah sistematis dan ilmiah sehingga diharapkan dapat mengatasi kesulitan siswa dalam memperoleh pengetahuannya. Selain kelebihan, PjBL dan PBL memiliki perbedaan mendasar yang perlu diperhatikan. Dalam penelitian ini, materi yang dibelajarkan yaitu pencemaran lingkungan (Enggar $d k k, 2016$ ).

Addiin (2014) Dalam penelitian pada materi pokok larutan asam dan basa disebutkan bahwa siswa dengan model pembelajaran berbasis proyek mempunyai rata-rata prestasi belajar lebih tinggi daripada siswa kelas lain dengan model ceramah. Hasil penelitian ini sesuai dengan penelitian Rachman (2013) mengungkapkan bahwa melalui pembelajaran berbasis proyek hasil belajar lebih tinggi dibandingkan dengan pembelajaran praktikum dan ceramah. Penelitian Benny $d k k$ (2014) menunjukkan bahwa siswa mudah memahami materi dengan menggunakan bahan ajar model pembelajaran berbasis masalah sebab dapat meningkatkan minat siswa melalui aktivitas sehingga siswa merasa tidak bosan dengan materi yang disajikan.

Model pembelajaran PjBL dan PBL diharapkan mampu memperoleh rata-rata hasil belajar lebih tinggi daripada siswa kelas lain dengan model ceramah. Dengan demikian siswa lebih aktif dan kreatif dalam mengikuti proses pembelajaran.

\section{METODE PENELITIAN}

Penelitian ini dilaksanakan di SMA Negeri 1 Bendahara di Jalan Sungai IyuUpah km 5 Desa Seunebok Dalam, Kecamatan Bendahara, Kabupaten Aceh Tamiang pada semester genap tahun pelajaran 2015/2016. Penelitian ini dilaksanakan pada bulan 24 Februari- 07 Mei 2016. Populasi penelitian adalah seluruh siswa kelas X SMA Negeri 1 Bendahara tahun pelajaran 2015/2016 berjumlah 120 siswa. Sampel pada penelitian ini adalah 3 kelas reguler dengan jumlah 90 siswa yang diambil dengan dengan teknik Purposive Sampling (sampel 
bertujuan). Pengambilan sampel ini dipilih berdasarkan atas pertimbangan khusus yaitu kelas yang diajarkan hanya kelas reguler saja sehingga diperoleh kelas $\mathrm{X}_{2}(\mathrm{PjBL})$, $\mathrm{X}_{3}$ (PBL) dan $\mathrm{X}_{4}$ (Kontrol).

Metode penelitian ini termasuk Quasi Experimental design dengan desain penelitian pretest and protest control group design. Data diperoleh dengan menganalisis nilai pretes dan postes siswa. Teknik analisis data menggunakan analisis kovarians (Anacova). Sebelum pengujian hipotesis terlebih dahulu dilakukan uji prasyarat terhadap data dengan menggunakan uji normalitas dan uji homogenitas pada taraf signifikan 0,05 menggunakan program SPSS 21 for windows.

\section{HASIL DAN PEMBAHASAN Hasil Penelitian}

Berdasarkan penelitian yang telah dilakukan, hasil pretes dan postes kelas eksperimen dan kelas kontrol disajikan pada Tabel 1.

Tabel 1. Hasil pretes dan postes kelas eksperimen dan kelas kontrol.

\begin{tabular}{lllccc}
\hline \multirow{2}{*}{ No } & \multirow{2}{*}{ Nilai Hasil Belajar Biologi } & \multicolumn{3}{c}{ Kelas } \\
\cline { 4 - 5 } \multirow{2}{*}{1} & \multirow{2}{*}{ pretes } & Tinggi & A & B & C \\
& & rendah & 50 & 47,5 & 47,5 \\
& Rata-rata & & 25 & 25 & 25 \\
\hline \multirow{2}{*}{2} & \multirow{2}{*}{ postes } & Tinggi & 98,83 & 38,16 & 34,91 \\
& Rata-rata & rendah & 77,5 & 70 & 70 \\
\hline
\end{tabular}

Keterangan:

$\mathrm{A}=$ Kelas PjBL

$\mathrm{B}=$ Kelas PBL

$\mathrm{C}=$ Kelas kontrol

Berdasarkan data hasil penelitian Tabel. 1 terlihat bahwa nilai rata-rata pretes dan postes di kelas ekperimen lebih tinggi dibandingkan dengan kelas kontrol. Data pretes dan postes pada ke tiga kelas berdistribusi normal. Pengaruh model pembelajaran (berbasis proyek, berbasis masalah dan konvensional) terhadap hasil belajar siswa dianalisis dengan teknik kovarians (Anacova) dengan bantuan SPSS 21.0 diperoleh bahwa ada pengaruh yang signifikan antara model pembelajaran (berbasis proyek, berbasis masalah dan konvensional) terhadap hasil belajar siswa kelas X SMAN 1 Bendahara. Hasil belajar siswa yang dibelajarkan dengan model pembelajaran berbasis proyek 86,83 $\pm 4,25$ sangat berbeda secara signifikan dengan model pembelajaran konvensional 79,58 \pm 5,25. Model pembelajaran berbasis proyek memberikan pengaruh sebesar 7,25 $(9,11 \%)$ lebih tinggi dibandingkan pembelajaran konvensional. Model pembelajaran berbasis masalah memberikan pengaruh sebesar 3,50 $(4,4 \%)$ lebih tinggi dibandingkan dengan pembelajaran konvensional.

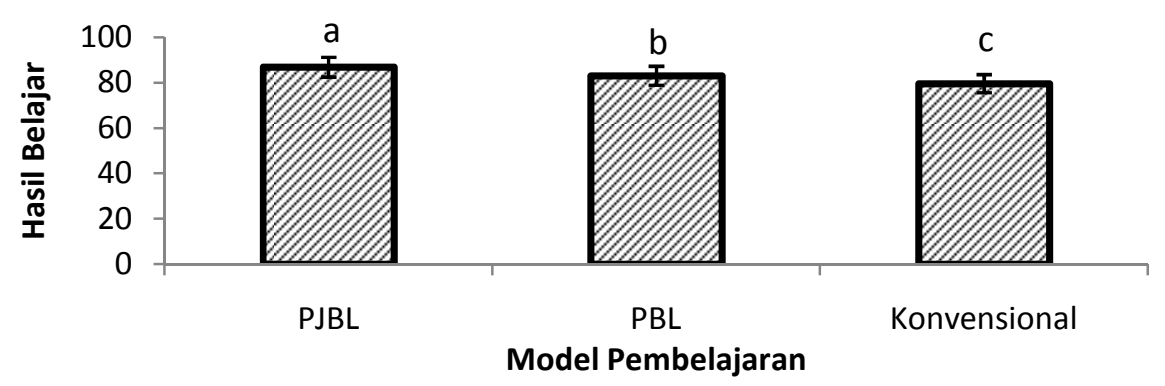

Gambar 1. Pengaruh Model Pembelajaran terhadap Hasil Belajar Siswa pada Materi Pencemaran Lingkungan di SMA Negeri 1 Bendahara Aceh Tamiang. $(F=16,46 ; P=0,000)$. Huruf yang berbeda di atas diagram berati berbeda signifikan (PJBL: Pembelajaran Berbasis Proyek, PBL: Pembelajaran Berbasis Masalah, dan Pembelajaran konvesional). 


\section{PEMBAHASAN \\ Pengaruh Model Pembelajaran terhadap Hasil Belajar Siswa}

Hasil penelitian diperoleh bahwa ada pengaruh yang signifikan antara model pembelajaran (berbasis proyek, berbasis masalah dan konvensional) terhadap hasil belajar siswa kelas X SMAN 1 Bendahara. Hasil uji lanjut menunjukkan bahwa hasil belajar yang dibelajarkan dengan model pembelajaran berbasis proyek sangat berbeda signifikan dengan model pembelajaran konvensional. Model pembelajaran berbasis masalah berbeda signifikan dengan model pembelajaran konvensional.

Perolehan hasil postes yang baik pada kelas ekspermen karena siswa tertarik dan termotivasi dengan pembelajaran berbasis proyek dan berbasis masalah. Pembelajaran berbasis proyek dan ini memiliki beberapa keunggulan, diantaranya dapat meningkatkan motivasi siswa (Muliawati, 2010). Dengan begitu maka hasil belajar siswapun meningkat dengan karena siswa mampu menerima pelajaran dan mampu menerapkan pemebelajaran dengan banar. Malaui tugas proyek dapat menjadikan siswa mandiri, melatih tanggungjawab siswa atas tugas yang telah diberikan oleh guru, mengajak siswa terlibat langsung dalam dan aktif dalam pembelajaran. Penggunaan Project Based Learning diketahui mampu meningkatkan kemampuan kognitif siswa di kelas kimia pada materi gugus fungsional (Johnson $d k k$, 2013).

Proyek itu dapat diselesaikan oleh siswa dengan memperhatkan beberapa petunjuk dalam proyek dengan mencari pengetahuan sendiri. Melalui penyelidikan, siswa belajar untuk bereksplorasi dengan cara berinteraksi dengan lingkungan yang ada disekitarnya. Interaksi siswa dilatih untuk belajar mandiri dalam memecahkan permasalahan yang ada dalam tuga proyek. Melalui penyelidikan siswa diberikan pengalaman langsung dan diberikan keempatan untuk mengkontruks pengetahuannya sendiri dengan memberikan kesempatan siswa untuk menuangkan ide-ide atas proyek yang dikerjakan. Pengalam langsung yang telah didapat oleh siswa dalam mengerjakan tugas atau proyek dapat menjadikan siswa lebih memahami materi sehingga hasil belajar yang didapat menjadi maksimal.

Hasil penelitian yang dilakukan oleh Widiyatmiko dan Pamelasari (2012) menunjukkkan bahwa pembelajaran berbasis proyek mampu mengembangkan dan menghasilkan alat peraga IPA dengan baik. Hal ini dapat diketahui dari penilaian produk yang telah dibuat siswa telah mendapat kategori baik. Menurut penelitian Widiyatmiko (2012) memaparkan bahwa pembelajaran berbasis proyek merupakan metode mengajar sistematik yang dapat melibatkan siswa untuk belajar memperoleh pengetahuan dan keterampilan melalui suatu pengembangan proses inkuiri yang distrukturisasi secara kompleks, dengan pertanyaan otentik dan didesain dengan hati-hati untuk memperoleh produk.

Namun dalam pembelajaran model Project Based Learning (PjBL) bukan berarti pembelajaran ini tidak memiliki kelemahan. Kelemahan tersebut antara lain pengerjaan proyek memerlukan waktu yang cukup lama. Selain itu hambatan yang berkaitan dengan proses pembelajaran ialah beberapa siswa kurang efisien menghimpun pengetahuan yang mereka peroleh. Siswa lebih mengutamakan cara membuat alat kalorimeter saja tanpa mengaitkan dengan konsep penentuan perubahan entalpi.

Pada pembelajaran berbasis masalah siswa dituntut untuk aktif di kelas dalam kerjasama dan mencari solusi dari permasalahan yang sedang dikaji melalui kegiatan tanya jawab. Masalah yang disajikan dibuktikan dalam kegiatan eksperimen yang menuntut setiap siswa dalam kelompok untuk ikut berpartisipasi menyampaikan pendapat melalui solusi dari permasalahan yang disajikan dari hasil diskusi kelompok. Keterlibatan lansung semua siswa mampu meningkatkan hasil belajar siswa terutama hasil belajar kofgnitif. Hal ini selajan dengan penelitian Ajai $d k k$ (2013) siswa pada tingkat sekolah menengah atas dalam materi aljabar yang dididik dengan pembelajaran berbasis masalah hasil prestasinya lebih tinggi 
daripada yang diajarkan menggunakan metode konvensional. Selain itu, menurut penelitian Asiatun (2013) menyimpulkan bahwa terdapat perbedaan yang signifikan secara simultan dan aktivitas dan pretasi belajar antara siswa yang belajar dengan model pemebalajaran berbasis masalah dengan model pembelajaran langsung pada pembelajaran IPA siswa kelas VII MTs Mu'allimat NW pancor.

Model pembelajaran berbasis masalah juga dapat meningkatkan kemampuan berpikir kritis dan kreatif siswa. Di dalam model ini siswa melakukan serangkaian aktivitas pembelajaran yang menekankan pada proses penyelesaian masalah yang dihadapi secara ilmiah. Dengan model pembelajaran ini siswa tidak diharapkan hanya sekedar mendengarkan, mencatat kemudian menghapal materi pelajaran, akan tetapi model pembelajaran berbasis masalah siswa diharapkan aktif berfikir, berkomunikasi, mencari dan mengolah data, serta akhirnya menyimpulkan. Dengan pembelajaran yang sedemikian rupa siswa dituntut untuk mampu memberikan solusi pemecahan masalah.

Model pembelajaran berbasis masalah memiliki kelebihan yaitu (1) pemecahan masalah merupakan teknik yang cukup bagus untuk lebih memahami isi pelajaran; (2) pemecahan masalah dapat menentang kemampiuan siswa serta memberikan kepuasan untuk menemukan pengetahuan baru bagi siswa; (3) pemecahan masalah dapat meningkatkan aktifitas pembelajaran siswa; (4) pemecahan masalah dapat membantu siswa bagaimana mentransfer pengetahuan mereka untuk memahami masalah dalam kehidupan nyata; dan (5) pemecahan masalah bisa memperlihatkan kepada siswa bahwa setiap mata pelajaran pada dasarnya merupakan cara berpikir, dan sesuatu yang harus dimengerti oleh siswa, bukan hanya sekedar belajar dari guru atau dari buku-buku saja (Sanjaya, 2010).

\section{KESIMPULAN}

Dari hasil penelitian dapat ditarik kesimpulan bahwa terdapat pengaruh model pembelajaran terhadap hasil belajar siswa pada materi pencemaran lingkungandi
SMAN 1 Bendahara Aceh Tamiang. Hasil belajar yang dibelajarkan dengan model pembelajaran berbasis proyek dan berbasis masalah lebih tinggi dibandingkan dengan model pembelajaran konvensional.

\section{DAFTAR PUSTAKA}

Addiin, I. 2014. Penerapan Model Pembelajaran Project Based Learning pada Materi Pokok Laruta Asam dan Basa di Kelas XI IPA 1 SMA Negeri 2 Karanganyar Tahun Ajaran 2013/2014. Jurnal Pendidikan Kimia, 3 (4): 7-16.

Ajai, J. T., Imoko, B. I., dan O'kwu, E. I. 2013. Comparison of the Learning Effectiveness of Problem-Based Learning (PBL) and Conventional method of teaching Algebra. Journal of Education and Practice, 4 (1): 131-135.

Asiatun, Marhaeni, A. A. I. N., dan Suastra, I. W. 2013. Pengaruh Penerapan Model Pembelajaran Berbasis Masalah Berorientasi Biodiversitas terhadap Aktivitas dan Prestasi Belajar IPA. E-journal Program Pascasarjana Universitas Pendidikan Ganesha, 3:1-10.

Ballanca, James. 2012. Proyek Pembelajaran yang Diperkaya: jalur Praktis Menuju Keterampilan Abad ke-21. Jakarta: Indeks.

Benny, S. W, Slamet, H., dan Salifah, A. H. 2014. Pengembang Bahan Ajar Berbasis Model Problem pada Pokok Bahasan Pencemaran Lingkungan untuk Meningkatkan Hasil Belajar Siswa Kelas X SMA Negeri Grunjugan Bondowoso. Jurnal Pancaran, 3 (3): 83-92.

Enggar, D., Sri Mulyani, dan Bakti Mulyani. 2016. Pengaruh Model Pembelajaran Project Based Learning dan Problem Based Learning pada Materi Termokimia terhadap Prestasi Belajar Siswa Kelas XI SMA Negeri 1 Karanganyar. Jurnal Pendidikan Kimia (JPK), 5 (1): 134-142.

Hayati, M.N., Supardi, K. I. dan Miswadi, S. S. 2013. Pengembangan Pembelajaran IPA SMK dengan Model Kontekstual Berbasis Proyek untuk Meningkatkan Hasil Belajar dan Keterampilan Proses Sains Siswa, Jurnal Pendidikan Program Studi IPA FMIPA UNNES Semarang, 2 (1): 53-58.

Johnson, Cynthia, S., dan Shannon, D. 2013. Project Based Learning and Student Engagement. Academic Research International, 4 (4): 560-570.

Kementerian Pendidikan nasional. 2007. Permendiknas No. 41 2007. Jakarta. 
Muliawati. 2010. Kelebihan dan kelemahan pembelajaran berbasis proyek online at http://id.shvoong.com/social sciences/education/2197626-kelebihan-dankelemahan-pembelajaran-berbasis-proyek/. Diunduh tanggal 14 februari 2014.

Rachman, N. 2013. Pengaruh Model Pembelajaran Berbasis Proyek terhadap Keterampilan Berpikir Kritis dan Kreatif Siswa Kelas VIII pada Materi Pertumbuhan dan Perkembangan Tumbuhan. Tesis. Bandung: PPS UPI.

Sanjaya, W. 2010. Strategi Pembelajaran Berorientasi Standar Proses Pendidikan. Jakarta: Kencana Prenada Media Group.
Sani, R.A. 2014. Inovasi pembelajaran. Medan: Bumi Aksara.

Wahyuningtyas, D., Harsastro, P., \& Supratiwi. (2013). Evaluasi Program Adiwiyata di SMAN 11 Semarang. Jurnal Ilmu Pemerintahan.

Widiyatmiko. 2012. Pembelajaran Berbasis Proyek untuk Mengembangkan Alat Peraga IPA dengan Memanfaatkan Bahan Bekas Pakai. Jurnal Pendidikan IPA indonesia, 10 (2): 23-28.

Widiyatmiko A dan SD Pamelasari. 2012. Pembelajaran Berbasis Proyek untuk Mengembangkan Alat Peraga IPA dengan Manfaat Bahan Bekas Pakai. Jurnal Pendidikan IPA Indonesia, (1): 51-56. 